
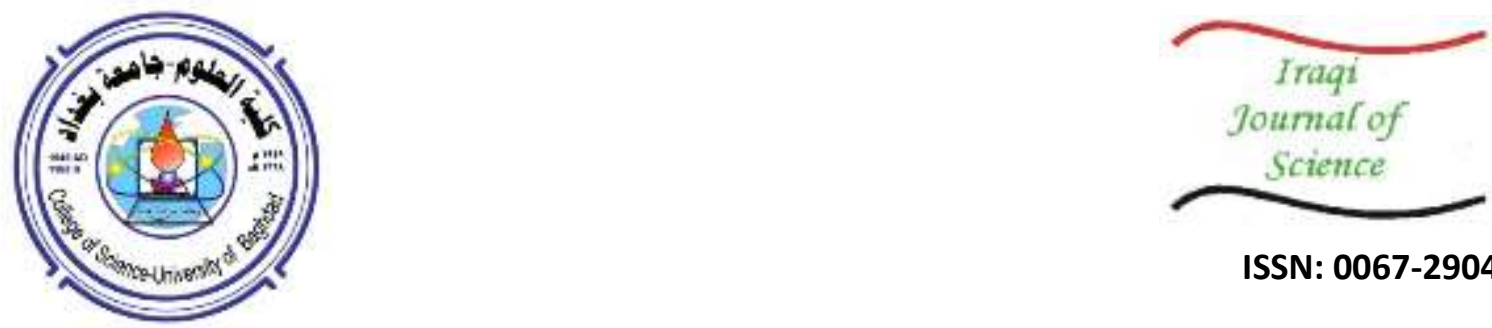

ISSN: 0067-2904

\title{
Monitoring the Change of Water Level and Its Effect on Water Quality in Sawa Lake, Southwest Iraq
}

\author{
Muhand. K. Al-Tememi*, Walaa. M. Al-Mosawi, Zuhair Ali Abdulnabi \\ Marine Science Center, University of Basra, Basra, Iraq
}

\begin{abstract}
Sawa Lake is considered one of the distinct closed water systems located in the southwestern part of Iraq. In last years, the lake has suffered from a significant decrease in the water depth reached $1.5 \mathrm{~m}$, thus the current study aims to monitor and analyse the change in water level, and identify causes and effect of this change on the lake hydrochemical properties by using analyzing cations and anions with the assistance of sub bottom profilers technique as well as obtained information from scientific diving.

The results revealed that the lake had an equilibrium state between feed up and withdrawal water as well as evaporation during history. In spite of the high evaporation rates in the region, this equilibrium state made the lake doesn't dry up completely or become as a high salinity water system as brine lakes or as the Dead sea system. The equilibrium state is due to recycling and washing process of salt water by filtration and leakage under the bottom of the lake through the recharge site, so, there is a replacement of water, the decreasing in the lake level is not only attributed to evaporation factor, the main reason for this decreasing resulted in reducing the supply of Dammam aquifer, which is considered the main water supply effecting of the lake.
\end{abstract}

Keywords: Sawa Lake; Water quality; Sub Bottom Profiler

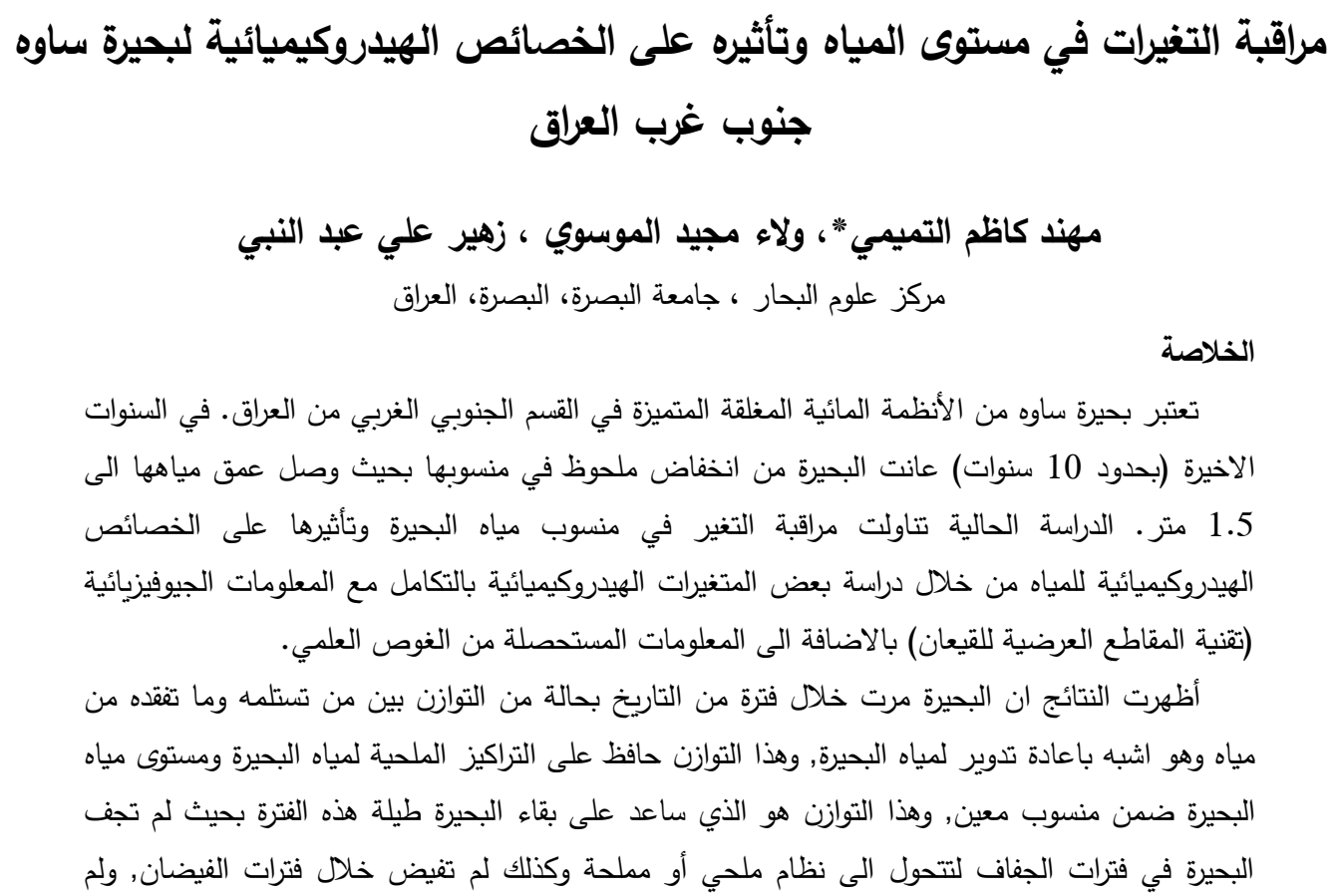

"Emails: mohanad7m@yahoo.com 


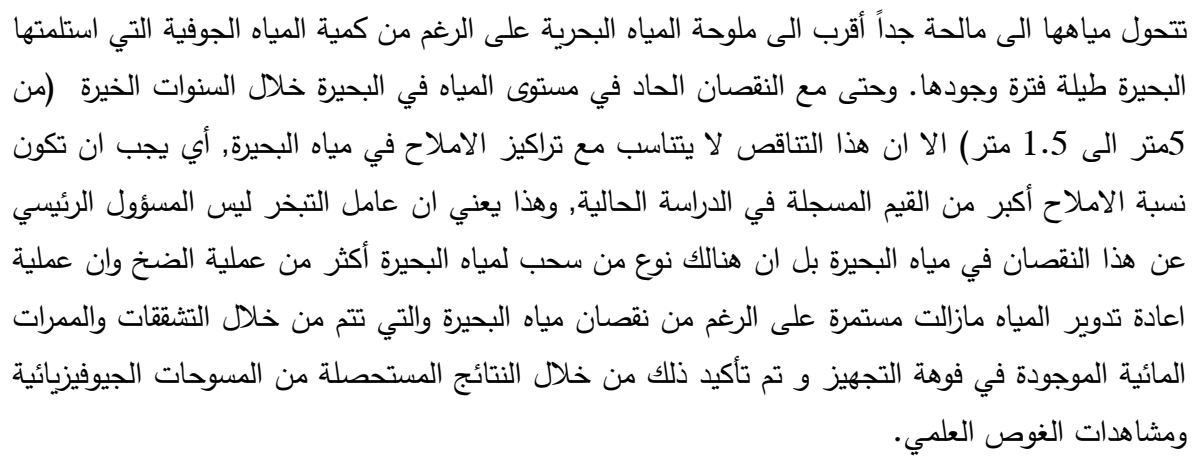

\section{Introduction}

Sawa Lake is a permanent lake, it is located in the western part of the Mesopotamian Plain, nearby the border with the Southern Desert. The lake is a closed water system in an area of Sabkha southwestern part of Iraq, about $23 \mathrm{~km}$ southwest of Al-Muthana Governorate, on the right bank of Euphrates River (Figure-1). It is listed as a wetland of international importance (Ramsar Site No.2240) in 2014. The lake is fed by groundwater of the Euphrates and Dammam aquifers through the system of joints, cracks, and fractures [1]. It is formed over limestone rock and is isolated with gypsum barriers surrounding the lake and also distinguishable by its unique water chemistry [2]. The lake exposed for strong evaporation, and many of recent studies of the lake showed that the depth of water decreased with the time. The water depth was $4-5 \mathrm{~m}$ before 35 years, while in the present time is shallower, ranged between $1 \mathrm{~m}$ in areas near the coast of the lake and $2 \mathrm{~m}$ in the lake center [3], this has caused decrease in the circumference of the lake from 12,258 $\mathrm{m}$ in 1990 to $11,388 \mathrm{~m}$ in 2012 [4].

The bottom of the lake a relatively regular and has not any diacritical features, except of the recharge site, which is appeared as a hole of $20 \mathrm{~m}$ depth and a longitudinal axis of $50 \mathrm{~m}$, and width ranging from 23.0 to $29.5 \mathrm{~m}$, where it was noted that the edges of the hole are rising of $1 \mathrm{~m}$ relative to surrounding areas of the lake bed and contain a number of fractures and cracks [3]. (Figure-2)

The previous researches and studies which have been conducted on Sawa Lake focused on water quality and concentrations of salts in different seasons [1]; [2]; [3] and [4], these studies haven't taken into consideration the change in water level during the completion of the studies and then compare the results, which has great significance in explaining changes to the lake, quality, and quantity. There are many changes took place in the lake including the dramatically decreasing in the water level during 35 years, as well as increasing the salt concentrations. Therefore, the present study aims to assess the hydrochemical situations of the lake and link it with change in the lake level during the years 2012 to 2017 periods, then identify the most parameter that controls on the quality and quantity of the lake.

\section{The Study Area}

Sawa Lake is located about $23 \mathrm{~km}$ to the west side of Muthana Governorate- southwestern part of Iraq, between longitudes ( $44^{\circ} 59^{\prime} 29.00^{\prime \prime}$ and $\left.45^{\circ} 01^{\prime} 46.60^{\prime \prime}\right)$ and Latitudes ( $31^{\circ} 17^{\prime} 43.11^{\prime \prime}$ and $31^{\circ}$ $\left.19^{\prime} 49.80^{\prime \prime}\right)$. the lake is a closed water system, it has an area about $4.7 \mathrm{Km}^{2}$, the maximum length of it about $5.13 \mathrm{~km}$, the maximum width of $1.936 \mathrm{~km}$ at the center part and minimum the width about 0.5 $\mathrm{km}$ at southeast of it (Figure-1). The land level of surrounding area of the lake is ranged about 13 in the east to $26 \mathrm{~m}$ to the west relative to sea level the lake. The topography of the lake bottom is slightly different, the western bank rises $1 \mathrm{~m}$ from the eastern bank [4]. 


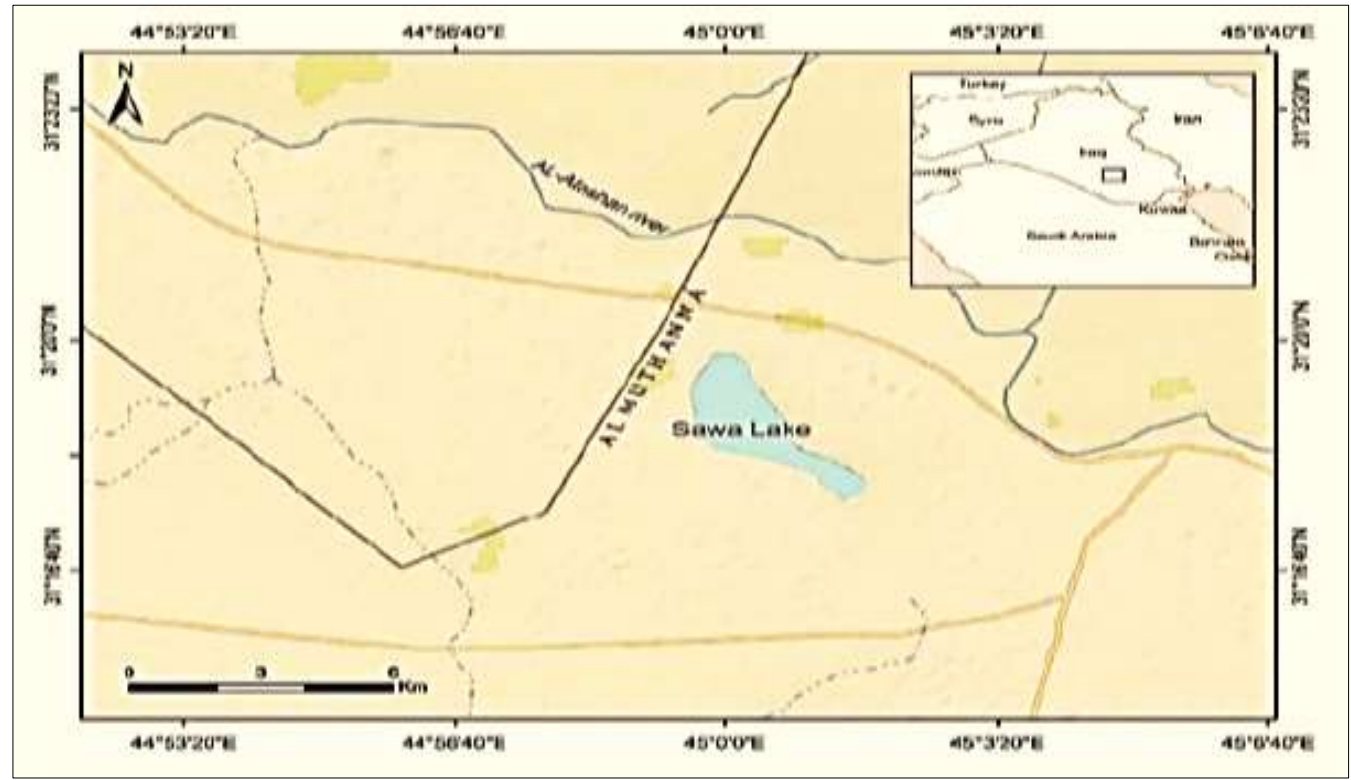

Figure 1-Location map of the study area and surrounding.

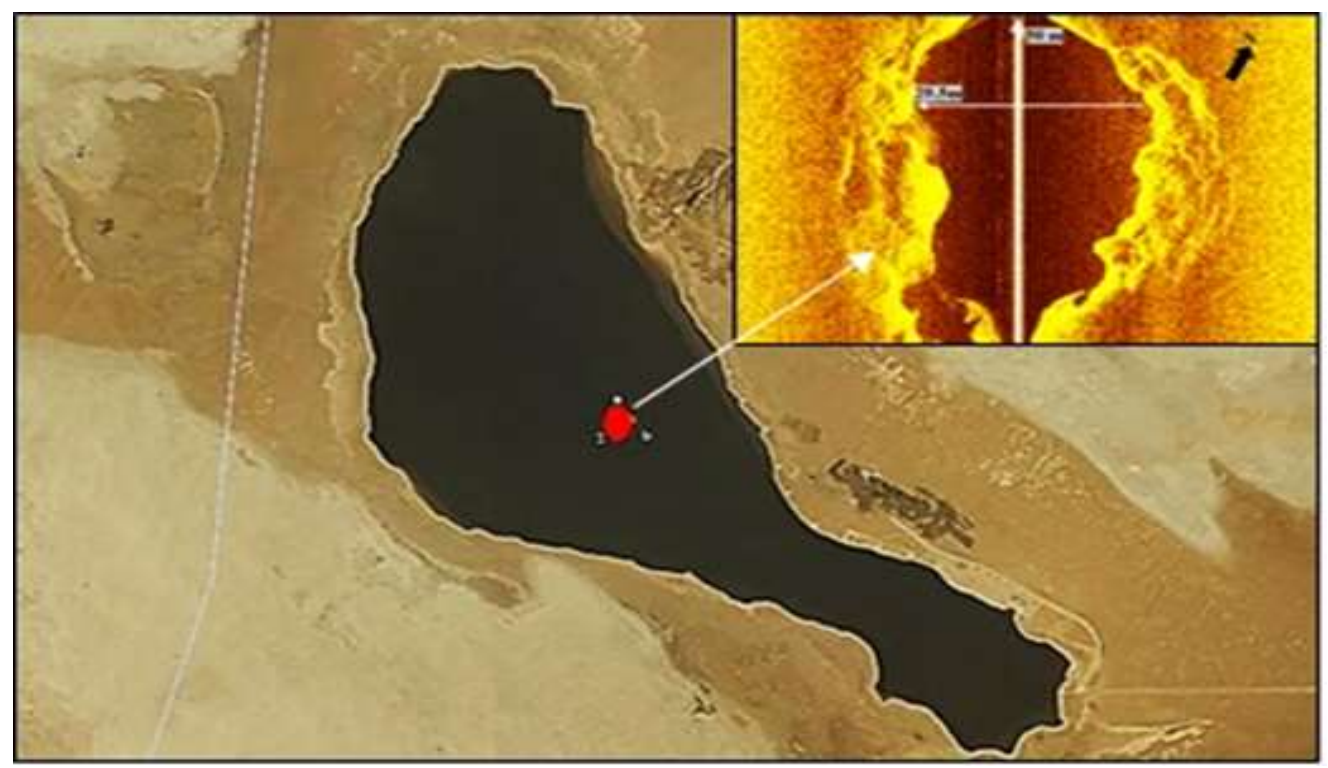

Figure 2-Recharge site of the lake that appear as a hole, image of the hole is extracted by side scan sonar technique [3].

Geologically, the area is covered by recent alluvial and sand dunes which vary in thickness from 1 to $10 \mathrm{~m}$, it is underlined by recent salts deposit. The formation in the study area from oldest to youngest according to [5] (Figure-3) can be described as Rus Formation (Jil) (Lower Eocene), it includes anhydrite alternating with marl, shale and limestone, the environment of it is Lagoonal [6].

Dammam Formation( L. Eocene); it includes variable carbonate rocks mainly limestone, dolomitic limestone, with chalky. It is characterized by the presence of cavities and karstic canals as well as fractures and joints. The sedimentary environment of this formation is shallow neritic.

Euphrates Formation (E. Miocene); it consists of limestone with textures ranging from o'olitic to chalky, which locally contain corals and shell coguinas [7]. However, in the study area, this formation consists mainly of limestone with impermeable clay and marl and hard, massive, cavernous, chalky limestone [5, 8]. The thickness of the formation is in the range of 30-40 $\mathrm{m}$.

Quaternary Sediments; it consists mainly of flood plain sediments, inland sebkha, salt deposits and gypcrete [9]. 


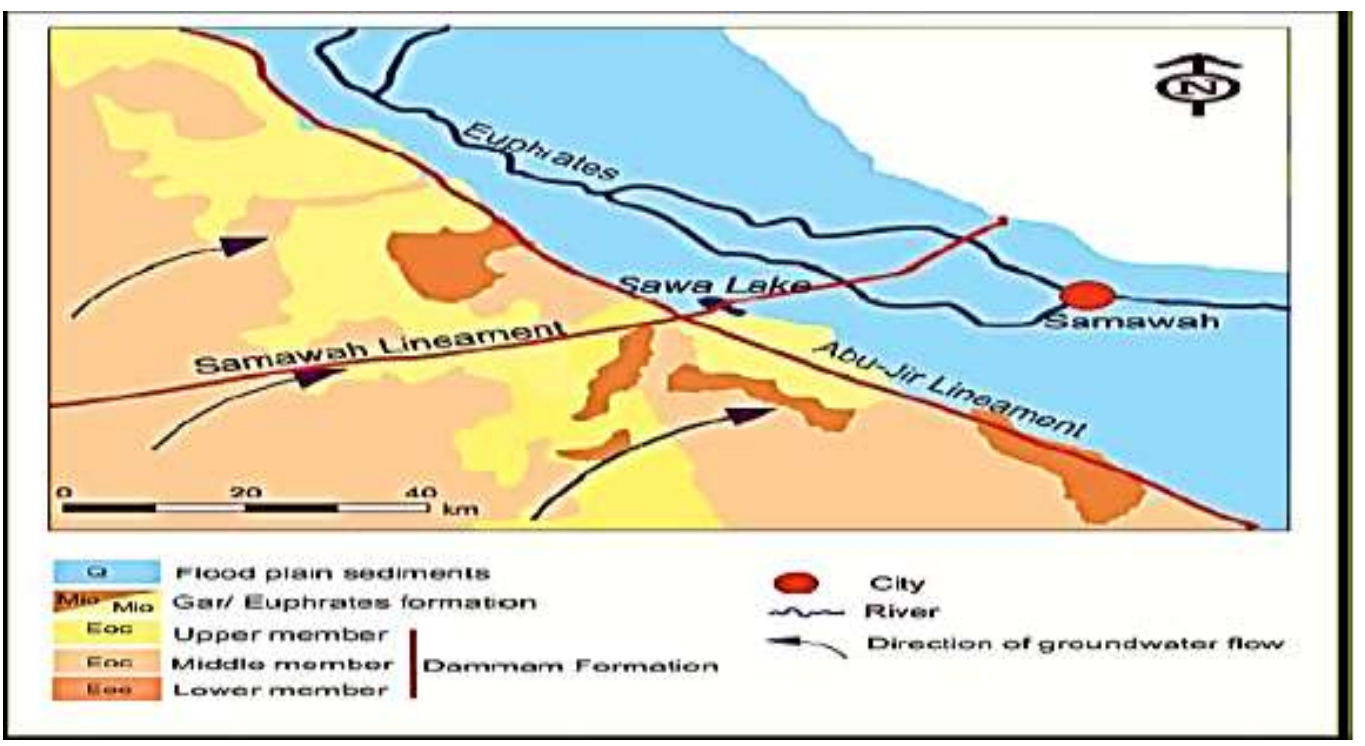

Figure 3-The geological map and simplified tectonic of the study area and surroundings $[9,10]$.

The structural geology is specifically represented by Euphrates Fault Zone (Abu-Jir Fault Zone) which cuts the region toward the NE - SW. Sawa Lake has no inlet and outlet flow, the water level fluctuates between summer and winter from 1 to 3 meters approximately. The lake lies on the eastern side of the Salman sub zone near to the western side of the Mesopotamian plain. The lake and surrounding area consists of two aquifers, from older to younger, Dammam and Euphrates aquifers [11].

\section{Methodology}

The hydrochemical analysis of the lakehad been conducted by collecting water samples from 20 sites in polyethylene bottles from the lakesurface and different interval depths with total of 40 the lake in 2012, 2015 and 2016. The collected samples have not been chosen for a particular season, the samples collected during of variable periods because the authors believe that the change in the level and water quality of Lake are not related frequently on rainy and arid seasons just, but by more influential factor which caused these variations annually rather than seasonally. The samples are not collected during 2013 and 2014 because of the absence of suitable conditions of work.

Water samples have been used to measure many of hydrochemical variation, as well as anions and cations. In situ, the Ec, salinity and pH have been measured by using WTW 3110 and WTW3210 devices respectively. Major ions $\left(\mathrm{Ca}^{++}, \mathrm{Mg}^{++}, \mathrm{Na}^{+}, \mathrm{K}^{+}, \mathrm{CO}_{3}{ }^{=}, \mathrm{HCO}_{3}{ }^{-}, \mathrm{Cl}^{-}, \mathrm{SO}_{4}{ }^{-}\right)$were analyzed according to standard methods as described in APHA (2005). $\mathrm{Ca}^{++}$and $\mathrm{Mg}^{++}$are titrated with $0.01 \mathrm{~N}$ $\mathrm{Na}_{2}$ EDTA. Sodium and potassium are determined by flame photometer (JENWAY PEP7). $\mathrm{Cl}^{-}$was determined volumetrically by titration with $0.01 \mathrm{~N} \mathrm{AgNO}_{3}$. The carbonate $\left(\mathrm{CO}_{3}{ }^{2-}\right)$ and bicarbonate $\left(\mathrm{HCO}_{3}{ }^{-}\right)$were analyzed by titration with $\mathrm{HCl}$. The sulfate $\mathrm{SO}^{=}$concentration measured by depositional method with $\mathrm{BaCl}_{2}$, then determined by spectrophotometer (CEIL CE292) using turbidity method).

Field work included 1: Imaging the sub-bottom of the lake was carried out by Sub Bottom Profiler technique (SBP), it is an acoustic marine survey that identifies a sub-bottom by transfer an acoustic signal to the bottom through means of a transducer, the acoustic signal reflections registered by a receiver and are upon a material in the bottom(clay, silt, sand and any sediments or rocks). The SBP investigation has been performed using the Strata Box ${ }^{\mathrm{TM}}$ Instrument (Figure-(4 A and B), it is a portable high-resolution marine geophysical instrument, it is capable to detect $6 \mathrm{~cm}$ of sub-bottom marine sediment strata resolution underneath the sea-floors and rivers with penetration of up to 40 meters by low power using $10 \mathrm{kHz}$. When using strata box equipment for sub bottom profilers survey, the distance between the transducer and the bottom should not less than $2.5 \mathrm{~m}$. Because of the shallow depth of the lake(not exceed $1.5 \mathrm{~m}$ ), the performance SBP survey for all the lake is useless. The reflectors of the lake bottom beds do not appear in the SBP sections, so this survey was limited to the recharge site to identify features on both sides of this site. SBP used to image under the bottom of 
the lake in the supply site that fed the lake with water, SBP profiler was completed towards the longitudinal axis of the site with a distance of $70 \mathrm{~m}$.

2: Level survey was used to identify the water levels of the lake comparing with surrounding area depending on the control station to observe the changes in the level of the lake in 2012, 2015 and 2016 for the purpose of evaluating the change in water level on the water chemistry, this survey was performed using (Trimble 5700) equipment Figure-( $3 \mathrm{C})$. Also, the results of the present study compared with the study completed by Jamil et.al.[11]for the purpose of this comparison, as well as relying on the previous studies and reports undertaken by the Marine Science Center (data observation of scientific diving in 2012 and 2015 ).
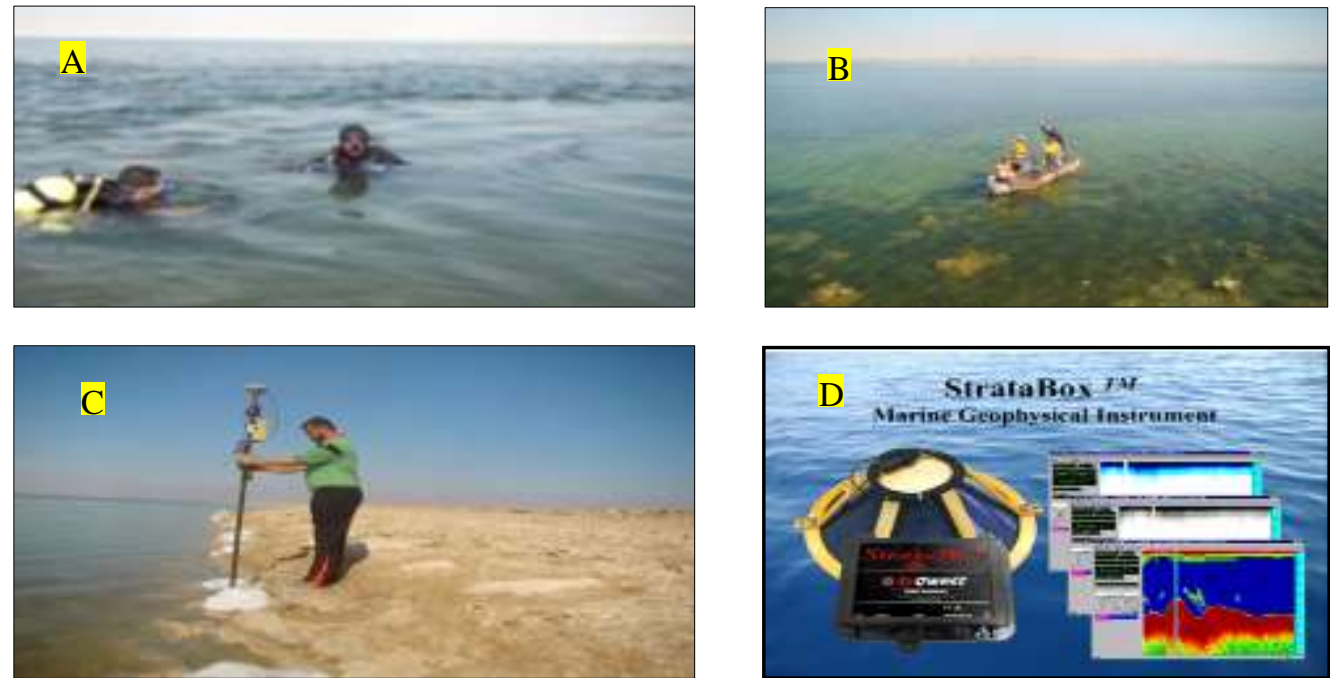

Figure 4-The survey work and instruments, A. scientific diving, B. survey boat that used for water sampling and SBP survey, C. Trimble 5700 that used for topographic and water level measurements, D. Strata Box instrument that used for SBP survey.

\section{Results and Discussion}

The obtained results in the present study have been compared with previous results that pointed out by Jamil et.al.[11], as shown in Table-1. The results clearly indicate that the evaporation process is not the only factor affecting the concentration of salts in the lake, where the amount of evaporation water from the lake must be proportional increase with increasing of concentrations of all salts according to the chemistry laws. However, some cations and anions may have the ability for sedimentation within these levels of concentrations, especially, sulphate and carbonate of calcium and magnesium then it's composed the gypsum and dolomite rocks. This clarifies the exist of depositional rock barrier during the time, which surrounds the lake from all sides that rises between 3- $6 \mathrm{~m}$ above the ground level around the lake Figure- $(5 \mathrm{~A})$. During ten years, the low discharge rate into the lake leads to receding of the coastline and expose parts of the lake bottom, thus leading to a rapid deposition processes of gypsum [12] as cauliflower structures (about $20 \mathrm{~cm}$ ), or natural gypsum sculpture on the shore of the lake and not exceeding of $90 \mathrm{~cm}$ as shown in Figure $-(4 \mathrm{~B}$ and C).
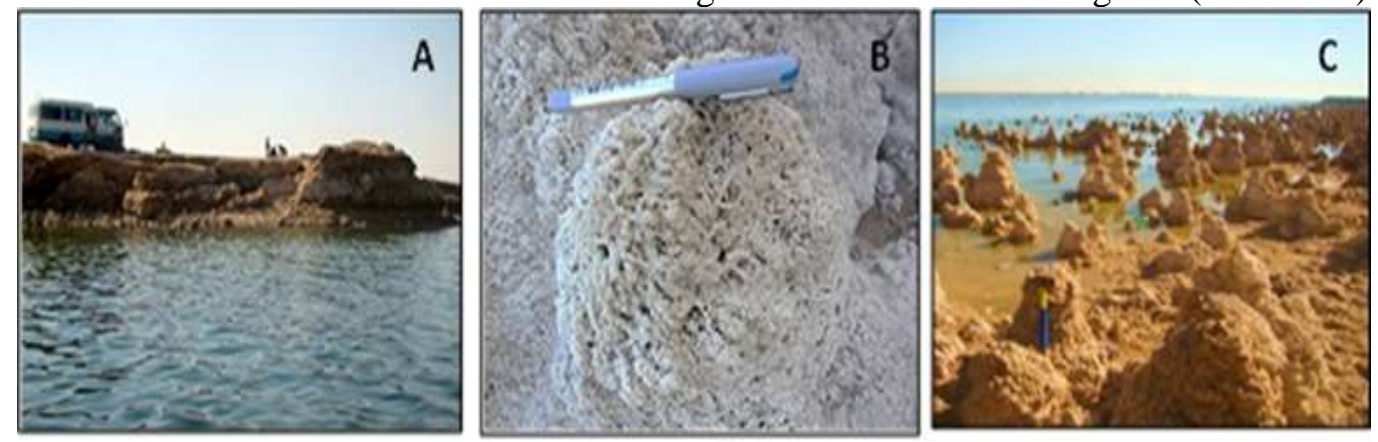

Figure 5-The gypsum barrier and sedimentary structures of Sawa Lake. A, barrier of the lake from all sides that rises between $3-6 \mathrm{~m}$ above the ground level. B, a cauliflower structures. C, natural gypsum sculpture 
Table 1-The average of the hydrochemical variation anions and cations and geometry of Sawa lake in year of 1977, 2012, 2015 and 2016.

\begin{tabular}{|c|c|c|c|c|}
\hline \multirow{2}{*}{ Hydrochemical variations } & \multicolumn{4}{|c|}{ Years } \\
\cline { 2 - 5 } Water depth (m) & 1977 & 2012 & 2015 & 2016 \\
\hline Circumference (m) & 5 & 2.1 & 1.3 & 1.3 \\
\hline Area (m ${ }^{2}$ & 12.5 & 11.39 & 11.20 & 11.20 \\
\hline Conductivity & 5.5 & 4.7 & 4.62 & 4.62 \\
\hline Salinity mg/l & - & 29720 & 38230 & 42110 \\
\hline $\mathrm{pH}$ & 18920 & 23350 & 25210 & 26653 \\
\hline $\mathrm{Na}^{+} \mathrm{ppm}$ & - & 8.32 & 8.35 & 8.36 \\
\hline $\mathrm{K}^{+} \mathrm{ppm}$ & 3220 & 7240 & 8255 & 8560 \\
\hline $\mathrm{Ca}^{++} \mathrm{ppm}$ & 112 & 255 & - & - \\
\hline $\mathrm{Mg}^{++} \mathrm{ppm}$ & 1060 & 1050 & 1090 & 1165 \\
\hline $\mathrm{Cl}^{-} \mathrm{ppm}$ & 1028 & & 2025 & 2330 \\
\hline $\mathrm{SO}_{4}{ }^{2} \mathrm{ppm}$ & 5148 & 8165 & 11300 & 11590 \\
\hline & 6432 & 8460 & 10620 & 11990 \\
\hline
\end{tabular}

The high solubility salts such as sodium, potassium and chlorides salts cannot be deposited (as salt minerals), where the lake salinity is less than sea water salinity (Table-1). The water depth in the lake declined from $5 \mathrm{~m}$ in 1977 to $1.3 \mathrm{~m}$ in 2015 (Figure -6), that means the present water amount is equal about a quarter of the past water amount, so, it is supposed the concentration of sodium, potassium, and chlorides had increased to four times at least, until assuming that groundwater feeds the lake by freshwater and not add new amounts of sodium, potassium and chloride ions to the lake. But this is the opposite of reality, the samples which have been taken from different depths of the hole that feed the lake contains is of salinity ranges from 8000 to $10000 \mathrm{ppm}$, and the sodium and chloride ions are the main ions. Thus, it was supposed to continue increase the concentrations of salts in the lake due to evaporation during the time and change the lake water to brine water or water have much higher concentrations than the marine water, then the lake and surroundings became as a salt flats, or the lake becomes as a closing salt lake as the Dead Sea system. In the Table-1, it can be observed that the concentrations difference are about doubled, while the decrease in the amount of water was four times. The supply site is fed the lake by mixing of the diluted marine waters of Euphrates aquifer [1] beneath and percolation of the meteoric waters of Dammam aquifer through many of sub bottom fractures.

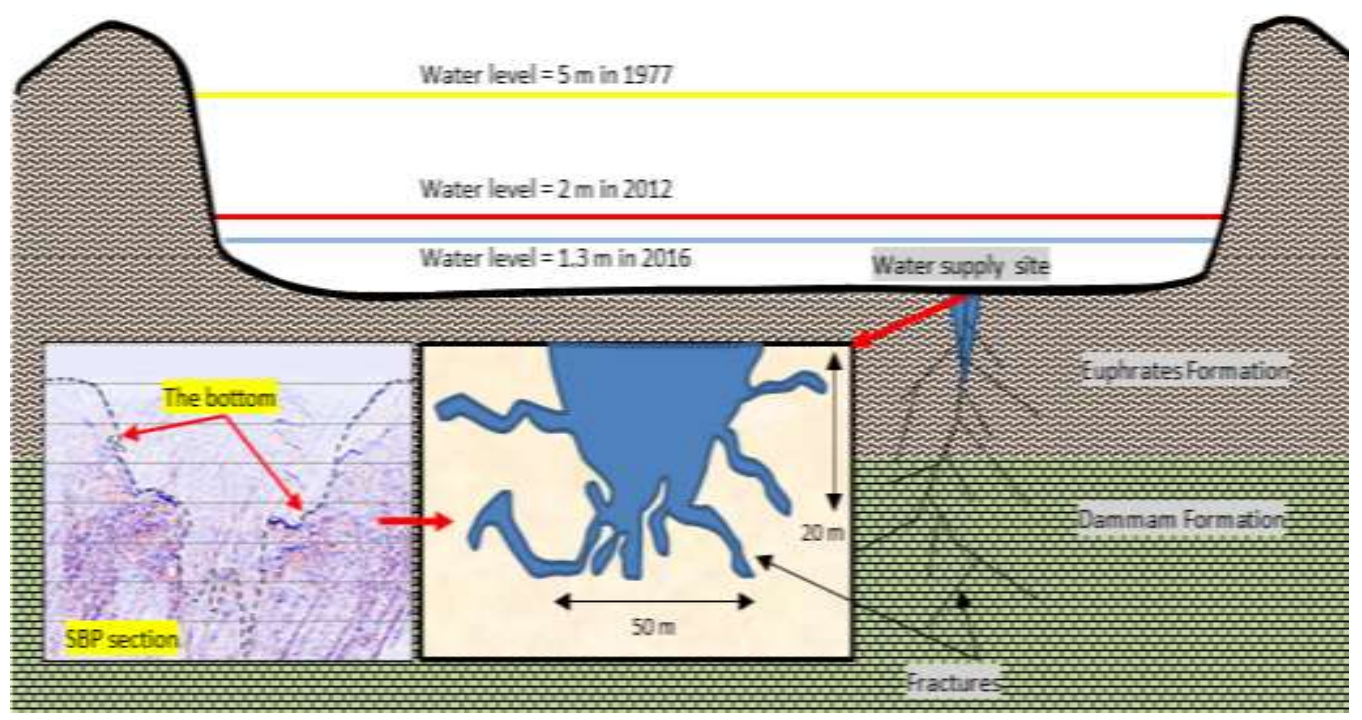

Figure 6-Schematic geologic cross section of Sawa Lake illustrates the water levels (water surface) for many years, recharged site is captured by SBP technique . 
From the chemical variations results in (Table-1) can indicate that the lake had equilibrium hydrological system may extend to hundreds of years, there was a case of withdrawal for the lake water and it is equivalent to the feeding process. The increase of saline concentrations in the lake does not depend solely on the quantity of water evaporating from the lake because the evaporation will cause a significant increase in salt concentrations in the lake water. The concentration ranges of sodium ions do not correspond to the quantity of large evaporated water, this gives clear evidence of the existence of underground channels and fractures that allow the release of high salinity water that is resulting from evaporation processes, and these channels and fractures compensated the lake with less saline groundwater. This case has been inferred by:

The first, exist of a gypsum barrier that surrounds the lake with high about 3-6 m and not floods the lake despite the large recharge from groundwater during the history. The second, there is not increase concentrations of sodium ions to values that correspond to the significant decrease of water level of the lake in recent years and it does not correspond to the amount of salts that have been added during the history from the site that feeds the lake which contains relatively high salt ratios $(9000$ ppm) [3], if this case occurred, the lake became as a saline system, even if the decrease in the lake level may be caused by decrease in water recharge processing from the groundwater reservoirs

The third, decline of the lake depth from $2.1 \mathrm{~m}$ to $1.3 \mathrm{~m}$ in 2013 and 2015 , and the lake level remains roughly constant of $1.3 \mathrm{~m}$ for the last three years (2015-2017), and there is no a significant increase in evaporation rates during the last five years. The forth, observations of the scientific diving team shown there's a withdrawal or recapture processing in the recharge site within of many subbottom fractures and galleries on both sides of the recharge site (Figure-7) .
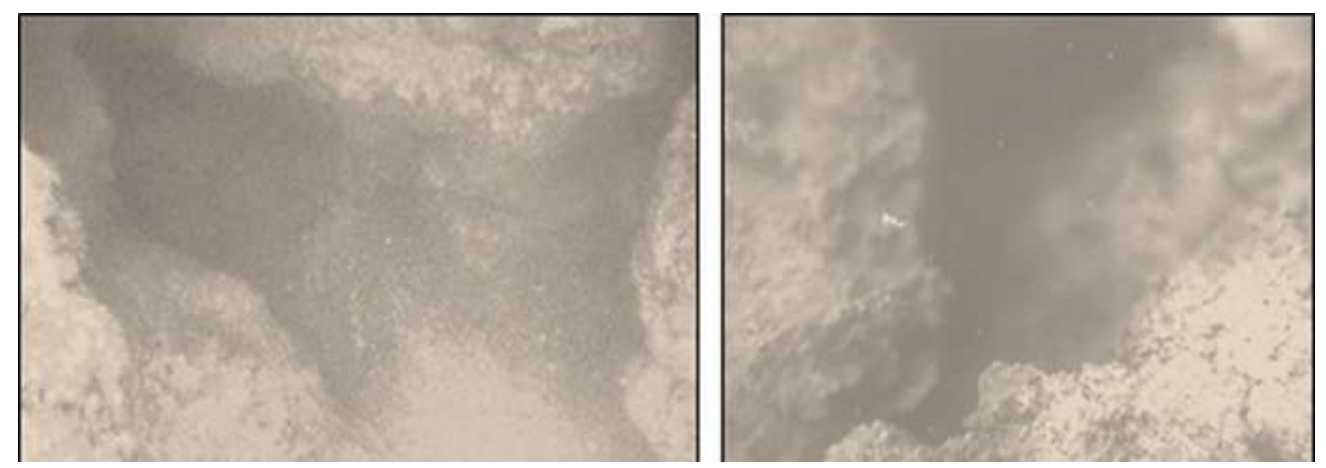

Figure 7-The sub bottom fractures and galleries on both sides of the recharge site at Sawa Lake, the photos are extracted by scientific diving team.

On the other hand, the lake is fed by mixing of the diluted marine waters of Euphrates aquifer beneath and percolation of the meteoric waters of Dammam aquifer, but Khayyun and Minaty [13] revealed that the water level in the lake is not affected by changing groundwater levels around the lake, not only that, but the quality of the lake water is different from the quality of groundwater for the wells surrounding the lake by Ali and Ajeena [14]. The presence of the gypsum wall which surrounds the lake prevents discharging water out of the lake, thus prevents occurs of washing processes release the lake from high salts concentrations that resulting from the extreme evaporation as a result of the shallow depth and wide surface area of the lake. Thus, the main reason for the decrease in the lake levels resulted in decrease the supply of Dammam aquifer, which is considered the main supplier effecting of the lake water, this confirms by there is not decrease in groundwater levels for the areas around the lake(Figure -8 ). 


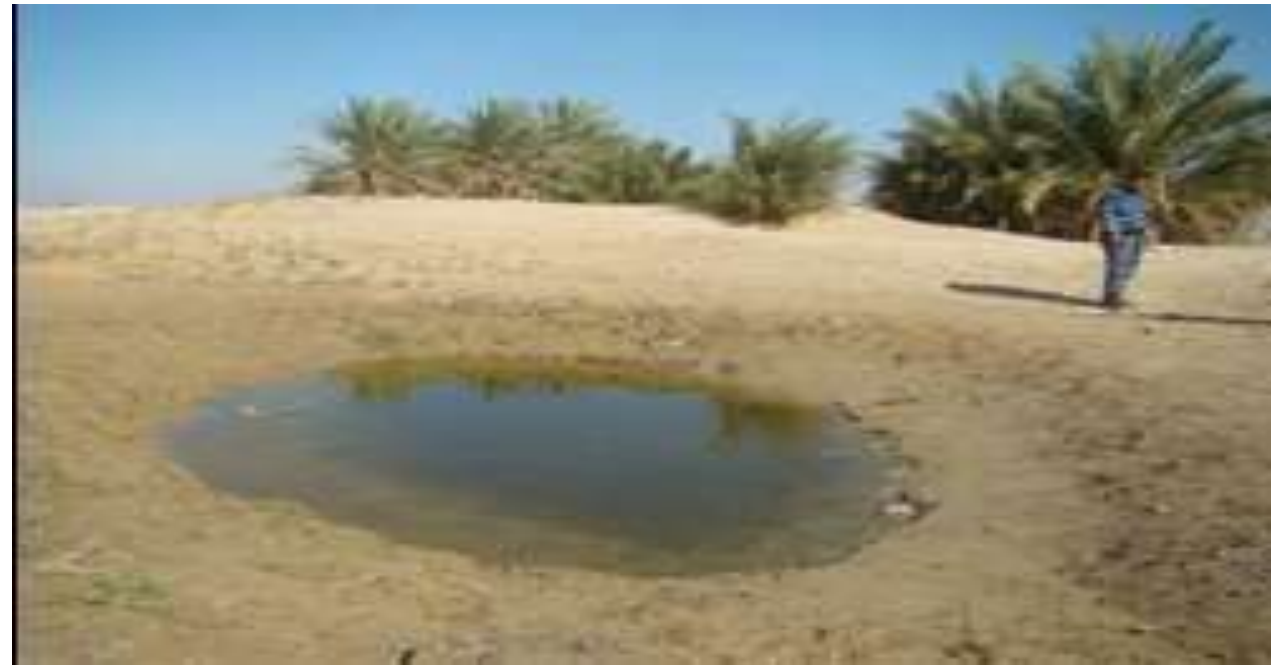

Figure 8-The groundwater level in a spring vicinity the lake.

The lithological nature of the area as a gypsum rock made passage lines for leaking and migration of the lake water, this is marked both from the SBP and scientific diving results on both sides of the fed site Figures - (5 and 6). These fractures and cavities exist at different depths and passage the water as springs. These springs are differenced in supply of water capacity according to location and depth, thus the waters are differenced in quality and quantity [3]. The existence of fracture and cavity sites within the lake bottom not resulting from melting of gypsum rock just, but influence the area by set of transverse faults which caused by Abu- Jir fault, (Figure-9), the presence of the lake has related to exist of this fault. The geomorphological units in the Southern Iraqi desert of which represented by structural denudation forms developed by the strike slip movement along Euphrates fault zone, like as plateau and tectonic depressions like as Bahr Al-Najaf, Hor Al-Milih, Sawa Lake, Samawa Saline and Slabiat Depressions [15]. This effect may be continued by neotectonic activation processes [16].

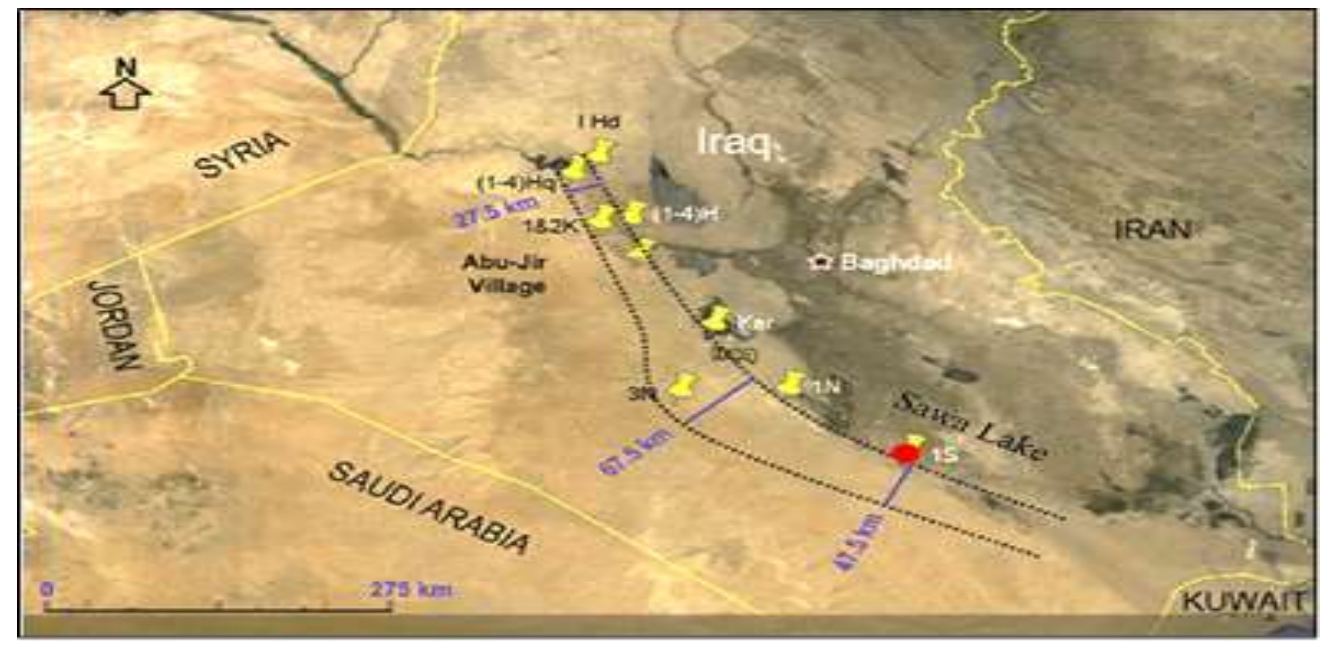

\section{Conclusions}

Figure 9-Surface extension of both width and length of Abu-Jir fault zone [10].

The current study was carried out in Sawa lake to monitor and analysed the change in water level, and identify causes and effect of this change on hydrochemical properties of the lake by analysing some of hydrochemical variations with assistance of sub bottom profilers technique as well as the obtained information from scientific diving.

The present study concluded there is a significant reduction of Lake levels during the past 40 years, especially during the last 10 years, where the water levels decreased from $5 \mathrm{~m}$ to $2 \mathrm{~m}$ and to 1.3 $\mathrm{m}$ in the years 1977, 2012, 2015 respectively. The present water amount is equal about a quarter of the past water amount, so, it is supposed to be the concentration of salts of sodium, potassium and 
chlorides had increased to four times at least. And it is supposed to continue to increase the concentrations of salts in the lake due to evaporation during the time and change the lakewater to brine water or water have much higher concentrations than the marine water, but this case has not occurred. The decreasing in the lake level is not only attributed to evaporation factor, the main reason for this decrease resulted in reducing the water supply of Dammam aquifer, which is considered the main supplier effecting of the lake water.

The main reason for not exceeding the lakewater to high levels of salt concentrations in spite of the high evaporation rates in the region is due to recycling and washing process of salt water by filtration and leakage under the bottom of the lake through the recharge site (hole), so, there is a replacement of saline water that produced from evaporation and it withdrawal by fractures in the bottom, then add less salty water through the recharge site.

\section{References}

1. Al- Rawi, N.N. 1975. Hydrogeology of Samawa Salt deposit internal report, SOM. Lib. Baghdad, 52p.

2. Al- Naqash, A., B. 1977. Hydrogeological and hydrochemical sediment petrographical study of Sawa Lake, Bulletin. College of Science, 18(1): 199-220.

3. Al-Mosawi W.M., Al-Tememi M.K., Ghalib H.B. and Nassar N.A. 2015. Sub-Bottom Profiler and Side Scan Sonar investigations, with the assistance of hydrochemical and isotopic analysis of Sawa Lake, Al-Muthana Governorate, Southern Iraq. Mesopotamian, Journal of Marine Science, 30(1): $81-97$.

4. Al-Abadi, D. 2013. Topogrraphic properties and ground forms of Sawa lake. M.Sc. Thesis, University of Thy-Qar, 125pp.

5. AL-Rawi, N., AL-Sam, S., and AL-Shavarka, L. 1983. Hydrogeological and hydrotechnical exploration in block 1, 2 and 3 (Southern Desert), final report on hydrogeology, hydrochemistry and water resources, Vol.9 SOM. Lib.204p.

6. Buday, T., 1980. Stratigraphy and Paleogeography in Kassab, I. M. and Jassim, S. Z. (eds.).The Regional Geology of Iraq( (1). Geological. Survey.and Mineral. Investigation. Baghdad, Iraq, 445p.

7. Jassim, S. Z. and Goff, J. C. 2006 Geology of Iraq, Published in Heritage Oil Corporation, 337p.

8. Al-Mubarak, M.A, and Amin, R.M. 1983. Report on the regional geological mapping of the eastern part of the Western Desert and Western part of the Southern Desert. GEOSURV, internal report.on.1380.

9. Sissakian, V.K. 2000. Geological Map of Iraq. Scale 1: 1000 000, 3rd ed. GEOSURV, Baghdad, Iraq.

10. Awadh, S. M., Ali, K. K. and Aazzaw, A. T. 2013. Geochemical exploration using surveys of spring water, hydrocarbon and gas seepage, and geobotany for determining the surface extension of Abu-Jir Fault Zone in Iraq: A new way for determining geometrical shapes of computational simulation models, Journal of Geochemical Exploration, Elsevier, 124: 218-229.

11. Jamil, A. K. 1977. Geological and hydrochemical aspects of Sawa Lake- S. Iraq, Bulletin, College of Science, 18 (1): 221-253.

12. Reed, A.H., 1975. Gypsum, in Mineral Facts and Problems, Bureau of Mines, Bulletin, 667.469477.

13. Khayyun T. S. and Minaty S. M. 2018. Groundwater flow and hydrologic budget for Sawa Lake in Iraq. International Journal of Scientific and Engineering Research, 9(6): 425- 430.

14. Ali, K. K. and Ajeena, A. R. 2016. Assessment of interconnection between surface water and groundwater in Sawa Lake area, southern Iraq, using stable isotope technique, Arabian Geoscience Journal, 9(14): 12517-016-2673-6.

15. Ma'ala K. 2009. Geomorphology of Iraqi Southern Desert, Iraqi Bulletin. Geol Min Special Issue.

16. Abd-Al-Abdan R. H. and Al-Gurairy A. S. 2018. Recent Morphotectonics Processes in Lower Valleys of Southern Desert, Iraq. Journal of Earth Science and Climatic Change. 8(8), DOI: $\underline{10.4172 / 2157-7617.1000407 .}$ 